\title{
Conception of an Effective Budget Process and Ways of Improvement Regional Budget Policy
}

Halyna Ostrovska, Ph.D. (Econ.), Assoc. Prof., Department of Management of Innovation Activity and Services Industry, Faculty of Economics and Management, Ternopil Ivan Pul'uj National Technical University, 56 Ruska Str., Ternopil, Ukraine.

E-mail: h.ostrovska@gmail.com

Vasyl Demianyshyn, Dr.Sc. (Econ.), Professor, Department of Finance named after Serhiy Yuriy, Faculty of Finance and Accounting, Ternopil National Economic University, 11 Lvivska Str., Ternopil, Ukraine. E-mail: v.g.demianyshyn@gmail.com

Liudmyla Maliuta, Dr.Sc. (Econ.), Assoc. Prof., Department of Management of Innovation Activity and Services Industry, Faculty of Economics and Management, Ternopil Ivan Pul'uj National Technical University, 56 Ruska Str., Ternopil, Ukraine.

E-mail: luda_mal@ukr.net

Roman Sherstiuk, Dr.Sc. (Econ.), Assistant of the Department of Management of Innovation Activity and Services Industry, Faculty of Economics and Management, Ternopil Ivan Pul'uj National Technical University, 56 Ruskastr., Ternopil, Ukraine. E-mail: romsher85@gmail.com

Tetiana Kuz, Ph. D (Econ.), Assistant of the Department of Management of Innovation Activity and Services Industry, Faculty of Economics and Management, Ternopil Ivan Pul'uj National Technical University, 56 Ruskastr., Ternopil, Ukraine.

E-mail: tanyasam1981@gmail.com

\begin{abstract}
The article deals with ways of improving regional budget policy and basic tools improve the budget process at the local level as one of the most important aspects of competitiveness. However, despite the large number of studies and publications, budget policy issues for individual municipalities, their inconsistency with the reform of local government, remain one of the main factors hindering the development of entrepreneurial and investment innovation and generally do not have enough in-depth research and coverage, and is a promising and relevant area for further research.
\end{abstract}

Keywords--- Improvement, Fiscal Policy, The Budget Process at the Local Level.

\section{Introduction}

The formation of an effective budget system is an integral part of the process of formation and development of a market economy. Socio-economic transformations in Ukraine that took place in the early 1990s led to a radical reform of the entire financial system of Ukraine and its main link - the budget system. At the same time, the role of the budget system in a market economy, as one of the most important instruments of regulation, in terms of limited opportunities to influence economic processes in the country by administrative means, has increased significantly. The most important direction of public finance reform was the formation of a three-tier budget system, which includes the state budget of Ukraine, regional and local budgets.

In the Ukrainian economy, the slow-moving processes of fiscal policy in relation to individual municipalities, their inconsistency with the reform of local government, remain one of the main factors hindering the development of entrepreneurial and investment activity. Changes in the system of local self-government are closely related to the general reform of the budget process, the aim of which is to create conditions and preconditions for the most effective management of state and municipal finances.

\section{Literature Review}

Analysis of the evolution of the role of local budgets in Ukraine shows that the historical features of the development of our state are the main reason that the regulation of local finances has traditionally been carried out «from above». The high level of centralization of power was caused by the fact that the system of local selfgovernment was not so much a product of civil society development as a «continuation» of the system of local government, a link between the inhabitants of certain territories and the state machine. A similar system of relations has defined the role of local finances, in particular the local budget, as secondary to the state, which seeks to mobilize the maximum amount of financial resources. At the same time, the level of decentralization of finances 
throughout the historical period of Ukraine's development, including the pre-revolutionary and Soviet eras, fluctuated depending on the degree of democratization of relations in the country.

The transition to market relations and the democratization of Ukrainian society in the early 90's of the twentieth century. served as a powerful stimulus to reform the system of local self-government.

The most significant contribution to the development of science to improve regional budget policy was made by scientists and practitioners, among which are the following: V.M. Danylyshyn, P.I. Gaidutsky, VM Geets, A.G. Zagorodniy, L.G.Chernyuk, O.V.Horska, H.A.Kuturichevskiy, V.A.Lushkyn, A.A. Kofanov, P.T. Sabluk, G.I. Onischuk, O.G.Osualenko, O.Ф. Novikova, NS Vlasenko, VI Topikha, L.I. Fedulov and others.

The main purpose of this article is to develop a concept and ways to improve the budget process at the local level using the proposed tools.

\section{Results}

The main goal of the reform is to increase the efficiency of the budget process at all levels of the budget, which poses fundamentally new tasks for local authorities: the transition to results-based budgeting, the principles of medium-term planning, and constant and objective monitoring of the budget process. The methodological basis of these mechanisms is still in the process of formation.

The concept of «efficiency» of the budget is disclosed in the Budget Code, which emphasizes that when preparing and executing budgets, authorized bodies and recipients of budget funds must proceed from the need to achieve the desired results using the least amount of money or achieve the best result using the budget.

Analysis of various sources allowed us to formulate the following definition of budget efficiency. In the most general form, efficiency is an indicator of performance, which is a comparison of the results of this activity, budget efficiency - is the level of optimization of consolidation and allocation of financial resources and the degree of achievement of specific socially important social and economic goals.

This approach significantly expands the prevailing view of budget efficiency, as the «degree of its implementation», or «economy» and «cost-effectiveness» and in modern conditions, determining the effectiveness of the budget should be part of the overall procedure for managing the financial condition of the state. budget in the permanent work of the financial apparatus.

The analysis of the existing points of view on the assessment of budget efficiency showed that they either duplicate the approaches adopted in the classical budget analysis, or differ in the abstractness and uncertainty of both the criterion and methodological approach. From the whole range of research work in this direction, we can highlight proposals for the formation of rating indicators of municipalities, as well as work where a system of performance indicators is formulated, taking into account both economic and social objectives.

In our opinion, the creation of a system of budget efficiency indicators implies a clear differentiation of the concepts of social efficiency (effectiveness) and economic efficiency. Efficiency should be understood as efficiency or social efficiency, the achievement of a certain social result per unit cost.

This approach involves distinguishing between the concepts of direct and final results of the budget process. By direct result we mean the volume of goods and services provided by local authorities - «issue». The final (social) results in these cases will be the support (achievement) of certain parameters of social development (quality of life). Achieving the final results with this approach is the goal of state (municipal) policy, and the production of works, goods and services by budgetary organizations is its tool.

Analysis of international experience shows that many countries around the world in order to increase the efficiency of the budget widely use methods such as RBB (results-based budgeting) and MTEF (medium-term planning) (Table 1). The world has accumulated more than half a century of experience in using such an approach to the budget process, while in Ukraine the cost method of budget formation still dominates, despite the declaration of budget effectiveness as its main goal. 
Table 1: The difference between Results-based Budgeting (RBB) and the Cost-based Budgeting Method

\begin{tabular}{|c|c|c|}
\hline $\begin{array}{c}\text { Budget planning and } \\
\text { approval }\end{array}$ & Cost method & RBB \\
\hline Planning tasks & $\begin{array}{l}\text { Distribution of total expenditures } \\
\text { between budget recipients }\end{array}$ & $\begin{array}{l}\text { Linking the volume and structure of budget expenditures } \\
\text { with the priorities of state (municipal) policy and its socially } \\
\text { significant expected and actual results }\end{array}$ \\
\hline $\begin{array}{l}\text { Basic approaches to } \\
\text { planning }\end{array}$ & $\begin{array}{l}\text { Planning in terms of departments and } \\
\text { their estimates }\end{array}$ & $\begin{array}{l}\text { Program-target approach (interdepartmental programs, } \\
\text { result indicators) }\end{array}$ \\
\hline Starting point of planning & Expenditure needs & Priorities, program results \\
\hline $\begin{array}{l}\text { The structure of budget } \\
\text { expenditures }\end{array}$ & $\begin{array}{l}\text { Priority of economic and } \\
\text { departmental classification }\end{array}$ & $\begin{array}{l}\text { Priority of program (improvement of functional) } \\
\text { classification }\end{array}$ \\
\hline $\begin{array}{l}\text { The format of the draft } \\
\text { budget law }\end{array}$ & $\begin{array}{l}\text { Does not provide information about } \\
\text { the planned results }\end{array}$ & Setting goals, results, measurable indicators of results \\
\hline Detailing of expenses & Very detailed & Aggregate costs \\
\hline $\begin{array}{l}\text { Legislators discuss and } \\
\text { approve }\end{array}$ & Detailed structure of expenditures & $\begin{array}{l}\text { Goals, results, performance indicators; aggregate } \\
\text { expenditure structure }\end{array}$ \\
\hline $\begin{array}{l}\text { Responsibility of the } \\
\text { subjects of the budget } \\
\text { process }\end{array}$ & For the targeted use of funds & For achieving the planned results with minimal costs \\
\hline $\begin{array}{l}\text { Independence of the } \\
\text { subjects of the budget } \\
\text { process }\end{array}$ & Limited & $\begin{array}{l}\text { Freedom to dispose of resources (within programs; partly } \\
\text { between programs and financial years) }\end{array}$ \\
\hline $\begin{array}{l}\text { Levels of decision } \\
\text { making }\end{array}$ & High degree of centralization & Delegation at the level of effective implementation \\
\hline Control system & $\begin{array}{l}\text { External control over activities } \\
\text { dominates }\end{array}$ & Internal self-control dominates \\
\hline Focus control & $\begin{array}{l}\text { "Target" (by type of expenditure) use } \\
\text { of budget funds in accordance with } \\
\text { the approved plan }\end{array}$ & $\begin{array}{l}\text { Achieving the planned results, the correctness of their } \\
\text { measurement }\end{array}$ \\
\hline $\begin{array}{l}\text { The main objects of } \\
\text { external control }\end{array}$ & Fractional cost items & $\begin{array}{l}\text { Results and total expenditures; quality of the internal control } \\
\text { system }\end{array}$ \\
\hline Budget Execution Report & $\begin{array}{l}\text { Actual expenditures relative to } \\
\text { approved }\end{array}$ & $\begin{array}{l}\text { Emphasis on achieving results, reasons for deviations, the } \\
\text { need to adjust programs }\end{array}$ \\
\hline Other reporting & & Monitoring reports in program evaluation \\
\hline \multicolumn{3}{|c|}{$\begin{array}{l}\text { In recent years, the principles of RBB have been implemented mainly at the upper level of the budget system } \\
\text { (partly at the regional level), with almost no impact on the local budget, where the estimated approach is still the } \\
\text { same. Thus, the classical Ukrainian approach "from above" to social, social and economic reforms is reproduced. } \\
\text { The study of the legal framework governing both the budget process in the country as a whole and the activities of } \\
\text { local authorities confirms the complete absence of norms that establish the principles of budget orientation on } \\
\text { results. This situation can turn the declared budget innovations into another "campaign", without leading to any }\end{array}$} \\
\hline
\end{tabular}

Improving the efficiency of the local budget is possible only through the introduction of the principles of resultoriented and medium-term planning, which requires:

- To adapt the mechanism of planning, implementation, control and evaluation of the local budget within the framework of RBB;

- To develop a basic system of criteria for social and economic efficiency, based on the budgetary powers assigned to local authorities and subject to qualitative and quantitative assessment. This system can be adjusted taking into account the territorial and socio-economic characteristics of a particular municipality.

Issues of improving budget planning and improving the efficiency of the local budget as a whole should be considered in conjunction with improving the system of municipal self-government, in this regard require their solution to the problem of over-regulation of the budget system networks of budgetary institutions, lack of incentives for effective service delivery.

Analysis of the implemented elements of program-target planning showed that the approved programs are usually declarative in nature, do not define mechanisms for achieving goals, do not formulate clear criteria on the basis of which the effectiveness of the elements of the Program of socio-economic development can be assessed. 
Thus, in accordance with such a program, the strategic goals of local authorities are to increase the living standards of the population, increase real incomes, and solve economic and social problems.

Such an approach to program-targeted budgeting is by no means a private problem of a separate municipality. The analysis of various state, departmental and regional programs shows that, as a rule, neither the goals nor their final results are formulated in the form of quantitative indicators. Legislation and bylaws do not answer the question of how the social and economic efficiency of the local budget will be assessed.

In our opinion, in the process of forming the budget of the municipality on the basis of program-targeted budgeting methods, a fundamentally different approach is needed. Thus, each of the goals (objectives) of the Program should be formulated in the form of quantitatively measurable indicators, it is necessary to specify the mechanism for assessing socio-economic efficiency. (Table 2)

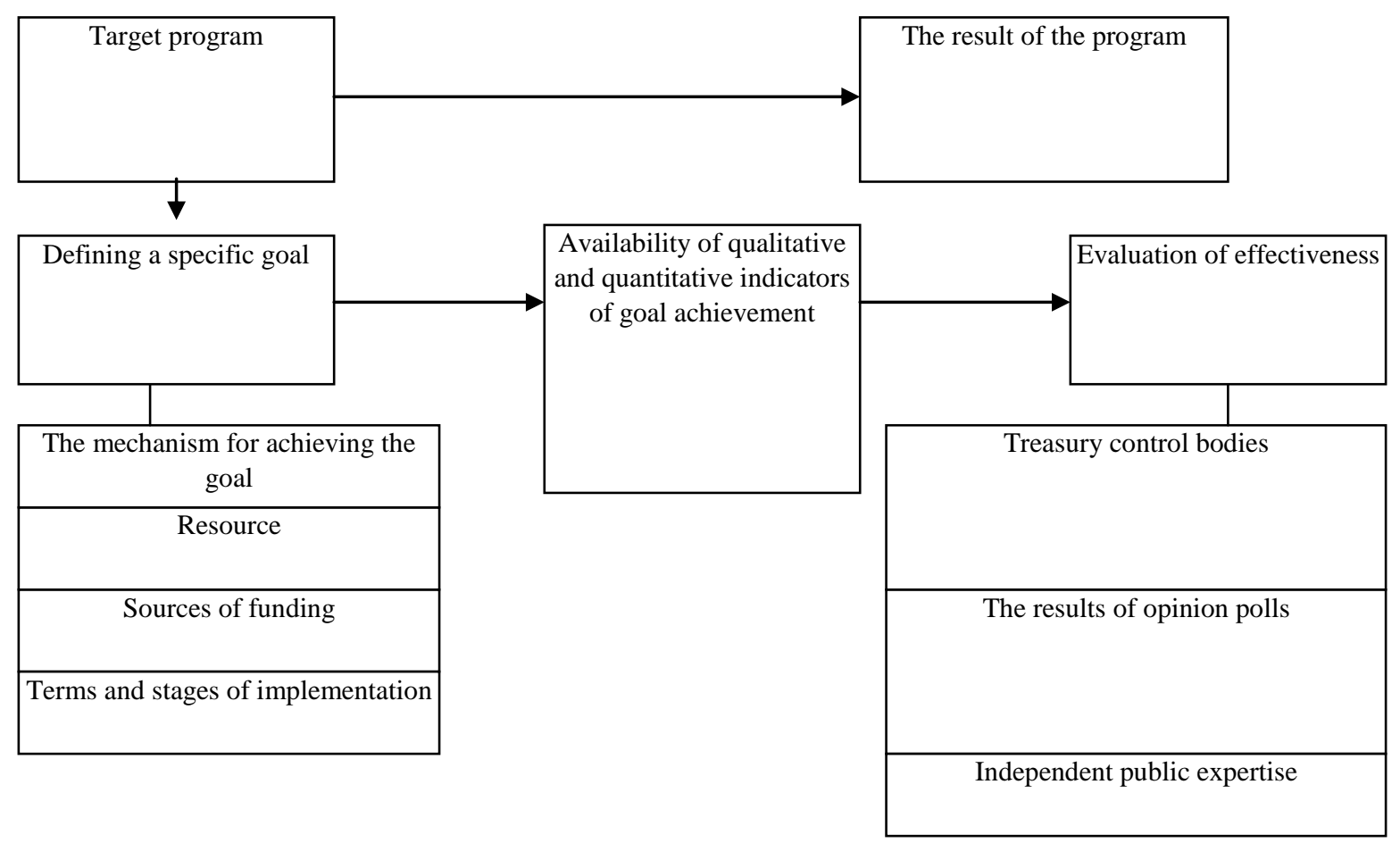

One of the elements of assessing socio-economic efficiency can be a survey of the population by independent sociological companies. Such an approach is widespread in countries that have switched to program-targeted budgeting, and is practically not used in Ukraine.

\section{Conclusions}

Therefore, the main tools for improving the budget process at the local level should be:

- Legislative consolidation of the principles of medium-term planning and result-oriented budgeting for budgets of all levels;

- Recognition of the fact that the maximum concentration of financial resources at the top of the government is only a forced stage in the development of the budget system. Stabilization in the financial sphere and a change in approaches to the budget, as a document designed to ensure effective consolidation and allocation of resources, should ultimately lead to greater decentralization of the budget system and real budget independence, including local authorities;

- Ensuring an effective system of control over the budgets of all levels, which provides for the creation of an adequate system of control and audit bodies;

- Ensuring real "transparency" of the budget, starting with the budgets of municipalities. This work should include not only the publication of budget laws (modern understanding of transparency), but also stimulating citizens' interest in such information (curricula, starting with school, targeted grants to study government finances, competitions for better knowledge of the financial system of the region or territory), the organization of public lectures and debates on the status and quality of budget execution. 


\section{References}

[1] Information support of state and regional social management / [O. G. Osaulenko, O.F. Novikova, N.S. Vlasenko and others]. - Kyiv, Donetsk: Institute of Industrial Economics of the National Academy of Sciences of Ukraine, Derzhkomstat of Ukraine, 2004. - $656 \mathrm{p}$.

[2] Productive forces of economic regions of Ukraine / [B. M. Danyly... Dr. econ. Sciences: 08.02 .03 / Vladimir Andreevich Lushkin. - Kharkov National shyn, L.G. Chernyuk, O.V. Gorskaya, etc.]. - K .: CJSC "NICHLAVA", 2000. - $520 \mathrm{p}$

[3] Budget Code of Ukraine // Voice of Ukraine. - 2010. - August 4.

[4] Kutorzhevsky G. A. Economics. Fundamentals of the theory: textbook. allowance. / G.A. Kutorzhevsky. M.: Economics, 2004 . -382 p.

[5] Lushkin V.l. A. Scientific and methodological foundations of state regulation of investment processes of economic development (regional and sectoral aspects): Dis University. V.N.Karazina. - H., 2002. - 508p.

[6] Kofanov A. A. Diversification of the economies of the Russian regions: a synthesis of experience and the legislative framework / A. A. Kofanov // Regional Economics: theory and practice. - 2010. - No. 3 (138). - p. 39-45.

[7] Onishchuk G.I. Urban complex of Ukraine: theory and practice of development: Dis. Dr. Econom. Sciences: 08.10.01. / George Ivanovich Onyschuk. - K., 2002. - 437 p. 